\title{
Quando jovens ativistas do hip hop encontram a política partidária
}

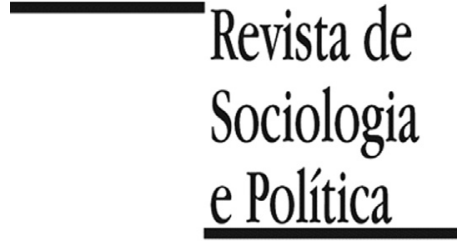

DOI 10.1590/1678-987317256101

\author{
Rosangela Carrilo Moreno e \\ Ana Maria Fonseca de Almeida
}

\section{Resumo}

O grau em que movimentos sociais podem se desenvolver associados a partidos políticos é uma questão relevante para a democracia participativa. Este artigo examina os efeitos ambíguos da aliança estabelecida entre jovens artistas e políticos profissionais numa grande cidade do interior paulista, no início dos anos 2000. O artigo explora uma abordagem interacionista da militância, percebendo-a como atividade social dinâmica e sublinhando sua dimensão temporal. Apoiando-se em entrevistas, o artigo mostra como a relação estabelecida entre jovens e um partido político contribuiu efetivamente para a construção do movimento hip hop da cidade. Progressivamente, no entanto, o crescente engajamento com as atividades partidárias dificultou uma maior dedicação à carreira artística por parte dos jovens, fazendo aumentar sua dependência com relação aos benefícios distribuídos pelo partido e, consequentemente, gerando disputas entre eles. Ocorrendo no período em que ingressavam na vida adulta, o processo culminou com a dissolução do grupo. Ao mostrar como essas relações se desenvolveram, o artigo revela as possibilidades e limites associados à interdependência entre movimentos sociais e partidos políticos, principalmente nos casos em que tais partidos assumem o governo.

PALAVRAS-CHAVE: militância; movimentos sociais; hip hop; política partidária; Brasil.

Recebido em 24 de Abril de 2015. Aceito em 8 de Dezembro de 2015.

\section{Introdução ${ }^{1}$}

\author{
${ }^{1}$ Agradecemos aos \\ comentários e sugestões dos \\ pareceristas anônimos da \\ Revista de Sociologia e \\ Política.
}

A análise da trajetória do grupo de jovens rappers negros que fundou o movimento hip hop na cidade de Campinas, nos anos de 1990 e início dos anos 2000, oferece elementos para compreendermos os obstáculos encontrados por ativistas para constituir uma força política durável. Foi esse grupo que liderou a criação de uma associação de rappers e, posteriormente, a aglutinação de outros segmentos do hip hop em torno de projetos comuns na esfera artística e política.

A partir de uma abordagem indutiva, inspirada numa perspectiva processual do ativismo, o artigo problematiza o final dessa história, isto é, a fase em que o grupo se desmobiliza, reunindo elementos que permitem compreender as forças que levaram ao processo de desengajamento dos jovens do movimento hip hop e, particularmente, do ativismo em torno das políticas culturais do município, desenvolvido até ali por meio da associação a um partido político.

Segundo Fillieule (2001) a partir da tradição interacionista, principalmente aquela associada a Hughes (1958) e Becker (1963), essa abordagem permite pensar o ativismo como uma atividade social e dinâmica, inscrita no tempo, como uma carreira (Becker \& Strauss 1956). Assim, para ser compreendida, é necessário adotar uma perspectiva longitudinal que permita tornar inteligível tanto a sucessão das fases quanto as mudanças de comportamento e de perspectiva vivenciada pelos indivíduos. Isso é o que torna possível identificar os mecanismos associados às transformações vivenciadas por eles, bem como a pluralidade de universos em que os próprios ativistas estão inscritos ${ }^{2}$.
${ }^{2}$ A perspectiva indutiva 
adotada nesse artigo, junto com o caráter particular da experiência discutida e o pequeno número de indivíduos implicados, são limites para a interpretativa geral sobre carreiras militantes, tal como pode ser visto em Becker (1953). O artigo limita-se, portanto, a explorar um insight fundamental da abordagem, demonstrando, no processo, sua utilidade para os estudos sobre o universo do ativismo. construção de uma proposta

Além disso, a análise processual do engajamento não se restringe apenas aos indivíduos. Empregando a noção de trajetória de grupo proposta por Sawicki (2003), é possível examinar como as regras e o modo de funcionamento das organizações no interior das quais esses indivíduos operam também variam ao longo do tempo, levando a modificações das relações que os indivíduos estabelecem com as mesmas.

Nesse sentido, o artigo se insere numa área mais ampla de estudos que busca levar em conta as transformações na ação coletiva ao longo do tempo, representada no Brasil pelos estudos recentes de Carlos (2012) e Dowbor (2012).

No caso em análise, a pesquisa mostrou que, a partir do momento em que o partido em cuja órbita os jovens circulavam assumiu a prefeitura da cidade, certas autoridades partidárias passaram a usar (a) o acesso a espaços e recursos controlados pelo mesmo e (b) o acesso a quadros partidários como instrumentos de um processo de seleção de militantes. Em outras palavras, como estímulo para que alguns jovens pudessem pensar e se projetar no futuro como lideranças partidárias em detrimento de outros, considerados menos promissores. $\mathrm{O}$ fato de nem todos poderem aspirar benefícios partidários teve efeitos importantes sobre os jovens, levando a mudanças na maneira como pensavam sobre si mesmos, como artistas e como ativistas, como indivíduos e como grupo, e a mudanças no lugar ocupado pelo movimento hip hop e pelo ativismo partidário na visão que tinham sobre seu próprio futuro.

Em paralelo a essas transformações, ocorria também uma mudança relacionada ao amadurecimento das relações amorosas em que os jovens estavam envolvidos e à chegada dos primeiros filhos. Se a própria condição de jovem, definida como o momento em que vários membros do grupo ganham mais autonomia com relação à família de origem, pode ser considerada como um dos elementos que ajudam a explicar seu ativismo, na medida em que parece liberá-los para o engajamento, simetricamente, a passagem para a vida adulta, implicando a necessidade de assumir todo um conjunto de novas responsabilidades, pode ser considerada como algo que contribuiu para levá-los a renunciar ao hip hop e à mobilização coletiva em torno de políticas culturais. Pelo menos no caso de alguns deles, isso levou ao próprio desengajamento da política partidária.

Para desenvolver o argumento, o artigo organiza essa história em três etapas consecutivas. A primeira se refere à fase de construção da aliança entre o grupo de jovens artistas do hip hop e alguns políticos profissionais atuantes na cidade, o que vai levá-los a se engajar na campanha eleitoral para a prefeitura. A segunda consiste na primeira crise vivenciada pelo grupo, ocorrida no momento em que disputam a inclusão do hip hop no grupo de atividades a serem apoiadas pela política cultural do município. Por fim, a terceira refere-se ao momento em que o grupo se extingue. Todo o processo aconteceu entre 1994 e 2003.

Antes, porém, apresentamos as operações de pesquisa que levaram à produção do material empírico analisado.

\section{A pesquisa}

O artigo baseia-se em entrevistas realizadas entre 2005 e 2006 com 14 jovens - 13 membros do grupo e um jovem rapper e empresário do rap, ao qual os demais se opunham - e dois indivíduos da esfera política - um político profissional que ocupava cargo legislativo na época da pesquisa e uma assessora de outro político, tanto ela quanto seu chefe muito envolvido com o movimento hip hop da cidade. Essas últimas entrevistas tiveram como objetivo estabelecer a cronologia das relações do partido político com os jovens e, principalmente, compreender a lógica político-partidária que orientou tais relações. 
${ }^{3}$ Isso é o contrário do que se vê tanto em famílias que experimentam forte mobilidade social, que costumam tratar a baixa escolarização e o pouco prestígio social do ponto de partida como uma prova do valor daqueles que alcançaram posições mais proeminentes, quanto em famílias dos grupos dominantes, que costumam construir uma narrativa apoiada sobre os feitos das gerações anteriores (Saint Martin, 1993).

\footnotetext{
${ }^{4}$ Duas versões resumidas desses quadros foram incluídas como apêndice nesse artigo.
}

Nas entrevistas com os jovens, sempre longas, solicitou-se um retorno reflexivo sobre as experiências que vivenciaram nesse período e também sobre sua história pessoal, incluindo aí a história do seu grupo familiar. As entrevistas obedeciam a um roteiro geral que dava margem para inversões, extrapolações e adendos. Em quatro casos foram realizadas mais de uma vez. Para todas as etapas, procuramos documentar as mudanças, ao longo do tempo, nas atitudes e nas percepções com relação ao engajamento no hip hop, na política cultural do município e na política partidária. Buscando algum grau de reflexividade, procurou-se documentar também suas apreciações sobre as decisões tomadas, assim como procurou-se obter algum tipo de análise dessas decisões ou do contexto de que foram cercadas. Para isso, os entrevistados foram estimulados a falar sobre as motivações objetivas que acreditavam, mesmo que a posteriori, ter sido consideradas no momento da decisão quanto o que pudessem acessar retrospectivamente em termos de explicações ou causas.

A análise dessas entrevistas teve como objetivo estabelecer, num primeiro eixo analítico, o percurso social dos jovens e de suas famílias, assim como a maneira como interpretaram esses percursos, com o objetivo de situá-los com relação à posição e à trajetória do grupo social mais amplo que os encampasse. Como se pode ver nos quadros-resumo incluídos no apêndice 1, há lacunas nas informações relativas à escolarização e ocupação de alguns dos avós. Como as entrevistas foram realizadas quando já eram adultos, tal desconhecimento parece indicar a ausência de uma narrativa familiar que desse proeminência à escolarização e à ocupação desses antepassados, indicando, provavelmente sua pouca contribuição para a história familiar ${ }^{3}$. Em pelo menos um dos casos, isso parece ter derivado também de um certo pudor em compartilhar detalhes de duras condições de vida.

Para a análise, foram construídos quadros de dupla entrada que permitiram comparar sempre que possível, por um lado, indicadores clássicos de posição e de trajetória social: local de nascimento e moradia atual dos avós, pais e do jovem em questão; ocupação e escolaridade dos avós, pais e mães; trajetória escolar do jovem (ano e nível de entrada na escola, nomes e localização das escolas que frequentou); experiências de trabalho remunerado; práticas culturais das famílias e dos próprios jovens; padrões de circulação pela cidade, entre outros. Por outro lado, os quadros permitiram comparar também as experiências subjetivas associadas às trajetórias sociais, em termos de privação e/ou vulnerabilidade por oposição a contentamento e/ou segurança; relação com as gerações mais velhas em termos dos padrões de imposição da autoridade em vigor nas famílias e expectativas quanto ao futuro; percepção de si em relação a outros (vizinhos, colegas de escola, autoridades institucionais como professores, polícia, médicos etc.) e às trajetórias militantes, no que diz respeito, em especial, aos modos de relação com o movimento hip hop e com o partido político ${ }^{4}$.

Para além das entrevistas, alguns desses jovens foram acompanhados em suas lides cotidianas, observados em seus locais de trabalho, em ensaios que aconteceram em suas casas, em eventos de hip hop em diferentes locais da cidade, em oficinas de hip hop em escolas e centros culturais e, por fim, em shows que realizaram em praças públicas e em escolas ao longo do período que durou a pesquisa.

As entrevistas e observações foram precedidas por um levantamento extensivo da documentação sobre o movimento hip hop na cidade. Entre as fontes mais produtivas estiveram os jornais locais e trabalhos acadêmicos. Esses materiais permitiram estabelecer uma cronologia do movimento e uma lista de atores sociais relevantes que, posteriormente, foram confrontadas com aquelas construídas por meio dos depoimentos coletados. 


\footnotetext{
5 Na época dos eventos tratados aqui, eles tinham entre 14 e 16 anos de idade. Quando foram realizadas as entrevistas tinham entre 18 e 20 anos. No período em que estiveram ativos no movimento, ainda moravam com suas famílias, dependiam delas para se manter e não tinham filhos nem esposos. Essa situação havia mudado para vários deles no momento das entrevistas.
}

\section{II.1. Uma história em comum}

O grupo de jovens era composto por dez garotos e quatro garotas ${ }^{5}$. Entre esses encontram-se alguns dos que ocuparam posições de liderança nos diferentes momentos da história do grupo. Outros estiveram em posições mais periféricas e seus depoimentos foram cruciais para revelar os efeitos das tensões vividas pelas lideranças sobre suas relações com o grupo mais amplo. Das quatro garotas, duas eram artistas do hip hop, uma delas com maior protagonismo no ativismo e outra ocupando posição mais periférica. As duas outras garotas não eram artistas do hip hop, nem ocuparam posições formais no movimento. Eram, no entanto, ativistas extremamente atuantes que desempenharam um papel crucial na organização do grupo. Foram elas, por exemplo, as responsáveis pela escrita dos primeiros manifestos e pela organização dos eventos anuais de rap, gerenciando as múltiplas frentes de trabalho necessárias para concretizar um grande evento. Reencontramos aqui, portanto, a mesma divisão sexual do trabalho já notada por outros autores em outros grupos políticos (Contamin 2007; Fillieule et al., 2007). Como mostramos a seguir, essa é apenas uma das clivagens que estruturava o grupo que, em geral partilhava aspectos fundamentais da experiência de crescer na periferia das grandes cidades brasileiras.

Entramos em contato com esses jovens em 2005, quando a Casa do Hip Hop, que havia aglutinado o movimento na cidade, sob a coordenação dos mesmos, já não funcionava como tal, em seguida à mudança de partido no comando da prefeitura.

Por meio das entrevistas e dos documentos consultados foi possível averiguar que o grupo se constituiu por volta de 1994. Além de negros e rappers, eram todos - com uma exceção - moradores de bairros pobres da cidade, afastados do centro. Aqueles que mais se destacaram nos processos de constituição do grupo cursavam os últimos anos do Ensino Médio em escolas públicas do centro da cidade.

Esse deslocamento para as escolas do centro contribuiu fundamentalmente para o encontro que daria origem ao grupo. Numa cidade onde a matrícula em uma escola determinada não é estritamente regulada pelo local de moradia, a procura por escolas do centro da cidade, percebidas como melhor aparelhadas e mais seguras, era e continua a ser uma estratégia bastante comum entre famílias que dispõem de mais informações sobre o sistema de ensino, como aliás acontece em outras cidades brasileiras (Costa \& Koslinski 2012; Ernica 2013; Koslinski \& Carvalho 2015; Alves et al., 2015). Com isso, elas acreditam que conseguem oferecer melhores chances de escolarização longa para seus filhos, distanciando-os das, em geral, dilapidadas escolas públicas de seus bairros.

A própria permanência na escola nesses anos já avançados do Ensino Médio, bastante incomum entre os jovens desse meio social mesmo hoje, sinalizava sua adesão ao forte investimento escolar realizado por suas famílias, de resto muito pouco escolarizadas, mas que haviam experimentado uma pequena ascensão social na geração dos pais e gozavam de alguma estabilidade econômica.

Campinas é um importante destino migratório para populações do próprio estado de São Paulo e também de outras regiões do país. Em meados dos anos 2000, apenas $42 \%$ da população era natural da região. Essa característica da cidade está impressa na trajetória dos pais e avós da maioria desses jovens, que vieram para a região em busca de melhores trabalhos.

A maior parte do grupo compartilha, assim, uma certa história familiar: avós analfabetos, trabalhadores rurais, que migraram para Campinas em busca de oportunidades no mercado de trabalho industrial. Seus pais e mães avançaram 
um pouco mais na escolarização do que a geração anterior, chegando às séries finais do Ensino Fundamental e, em poucos casos, ao Ensino Médio. Obtiveram empregos, no caso das mães, como empregadas domésticas, cozinheiras, acompanhantes em transporte escolar, vendedoras em pequenas lojas do centro da cidade e, em um caso, funcionária pública em cargo não especializado, enquanto os pais exerciam atividades de pedreiro, mecânico e, em um caso, empregado menos graduado em um banco (ver Quadro 1A do Apêndice 1).

Não foi por acaso, portanto, que seus pais e mães desenvolveram expectativas altas em relação aos filhos, investindo numa educação disciplinadora, apoiada em valores morais como dignidade, honestidade e trabalho, num esforço para afastá-los da lógica de violência e crime tão comuns nos bairros populares de Campinas. Trata-se, aliás, de uma recorrência nos estudos sobre o sucesso escolar nos grupos trabalhadores, a associação entre o bom desempenho escolar dos filhos e os investimentos das famílias decorrentes, esses últimos, de trajetórias de ascensão social, mesmo quando muito modestas (Lahire 1997).

\footnotetext{
"O meu pai me passou valores muito bons. Meu pai é uma pessoa super simples e, em alguns aspectos, uma pessoa conservadora. (...) Mas ele sempre me passou uma coisa assim de honestidade, de responsabilidade. Meu pai, mesmo que a gente sempre morou em periferia, nunca frequentou bar, nunca teve problema com álcool como muitas famílias às vezes tinham com o chefe da casa, que era o homem da casa, que trabalhava e no dia do pagamento gastava todo o dinheiro e chegava com uma mão na frente e outra atrás. Ou mesmo com drogas e essas coisas. O meu pai, nesse aspecto, sempre lutou muito para ter uma vida digna. Então, essa é uma coisa que eu guardo muito do meu pai. Agora a minha mãe (...) que só estudou até à quarta série, apesar disso é a pessoa que mais lê, sempre lê e é uma pessoa que tem visão. (...) Porque sempre me passou coisas super positivas, principalmente a questão dos estudos. Nunca me cobraram. Apesar de a gente ter passado por períodos difíceis do ponto de vista financeiro, a prioridade sempre foi estudar. Nunca me cobraram obrigatoriamente que eu tivesse que trabalhar, sempre priorizaram a questão dos estudos. Se desse para eu trabalhar tudo bem, mas se eu não quisesse trabalhar também nunca me obrigaram e eu acho isso importante para mim, porque possibilitou que eu tivesse estudado e eu acho isso daí positivo" (entrevista com Fabiano, Campinas, novembro de 2006).
}

"É criação bastante rígida, quando a gente é pequeno e filho único de mãe solteira, então pegava mais no pé. Não é por ser rígida assim com horário, mas rígida na questão de estudar, de ter responsabilidade. Nesse sentido assim que acho que isso ajudou muito no meu caráter (...), até porque eu sempre fui muito tranquilo. Eu sempre fui bem responsável, nunca fiquei..., nunca fui porra louca, então nunca tive problema com esse tipo de coisa" (entrevista com Ivo, Campinas, agosto de 2005).

No entanto, o pouco rendimento desse investimento já era percebido de maneira bastante clara por eles na época dos acontecimentos descritos aqui, quando já se encontravam no Ensino Médio. Em particular, a aposta na universidade, tão incentivada por seus pais e, principalmente, mães, passou progressivamente a ser vista como arriscada, com alta chance de dar em nada, pela dificuldade de ser aprovado em vestibular de universidade pública ou de arcar com os custos das mensalidades no Ensino Superior privado mais valorizado, que consideravam mais interessante. Iniciavam, assim, suas primeiras experiências no mercado de trabalho, em contratos precários e em posições subordinadas. Vários ocupavam postos de "ajudante", sob as ordens de empregados mais experientes, lidando com os aspectos menos atraentes do trabalho que desempenhavam em escritórios, restaurantes, etc. (ver Quadro 2A do Apêndice 1). 
${ }^{6}$ O norte-americano e o brasileiro são dois exemplos de rappers negros que à época falavam à imaginação desses e de outros jovens que se encontravam na mesma condição, cantando a condição racial e social dos bairros pobres e, em particular, as experiências dos jovens nesse contexto.
Em comum, encontramos também a proximidade com a música. Vários pais e/ou mães sabiam tocar instrumentos musicais e o faziam cotidianamente. Seus filhos e filhas se lembram de sessões musicais em casa quando eram crianças, com a participação de outros parentes, amigos da família e vizinhos. Alguns pais atuavam como "produtores de bailes" nos finais de semana, para melhorar o orçamento familiar. A música mais ouvida ou, melhor, a que os jovens afirmavam ter mais ouvido, pertencia ao circuito que, no Brasil, conhece-se como "música black". Vários jovens referiam-se com carinho às "coleções de discos" de seus pais, citando, em particular, músicos brasileiros, como Tim Maia, Jorge Ben Jor, Toni Tornado, e norte-americanos, como Anita Baker, Chaka Khan e Steve Wonder.

O deslocamento desses jovens para o centro da cidade, exigido pela matrícula nas escolas ali localizadas ou pelos empregos que obtinham, havia representado para eles uma ruptura com o padrão de sociabilidade vivenciado até então. Inaugurando uma nova forma de circulação pela cidade, ampliaram suas redes de amizades, até então circunscritas aos laços familiares e de vizinhança. À saída do bairro para o estudo e para o trabalho correspondeu a descoberta da vida cultural do centro. Já bastante atraídos pelo rap, com o qual haviam tomado contato em seus bairros no início da adolescência, passaram a frequentar shows de música, bailes e bares onde encontraram pessoas que se interessavam pela produção cultural do "circuito black" e, em particular, pelo rap.

Talvez por considerar difícil franquear as portas que levavam ao mais prestigiado Ensino Superior que, na sociedade brasileira, significava à época e significa, ainda hoje, a chance de alcançar uma renda de classe média e um trabalho não manual, esses jovens foram além da mera identificação com a produção de artistas como Chuck D e Mano Brown ${ }^{6}$, passando progressivamente a se interessar por se tornar eles próprios artistas do hip hop, compondo suas próprias músicas e arcando com os custos de produção de alguns CDs para divulgação. A aspiração não parecia fora de propósito. Afinal, muitos dos artistas consagrados pela mídia nesse período haviam partido de uma posição bastante similar à deles: eram negros, oriundos de regiões periféricas da cidade, que haviam se dedicado a denunciar, em suas canções, experiências de privação e relegação muito parecidas com as que vivenciavam.

Entretanto, logo descobriram que seria muito difícil conseguir espaço nesse universo de poucas oportunidades e alta competitividade. O mercado do rap em Campinas era pequeno e bastante fechado. As casas noturnas onde podiam se apresentar para uma plateia mais ampla, localizadas sem exceção no centro da cidade, eram escassas e controladas por "empresários do rap" cuja agenda, preenchida por grupos e artistas que eram garantia de receita, isto é, que já detinham um certo renome, encontrava-se pouco aberta a novos ingressantes. Quando conseguiam se apresentar nesses locais, não recebiam nada em troca, embora conseguissem arregimentar um bom público, em geral mobilizado por eles mesmos em seus bairros de origem, uma garotada empolgada por ver seus companheiros em posição de destaque num palco do centro da cidade.

Num certo momento, entre 1994 e 1995, após um período particularmente duro, que parecia desafiar qualquer esperança de carreira artística, começaram se reunir no centro da cidade de Campinas com o objetivo de trocar informações e experiências que lhes permitissem contornar essa situação. O ponto que os unia, portanto, era a queixa com relação aos empresários que mantinham as casas noturnas. Segundo eles, tais empresários lucravam com os bailes mas pagavam mal os rappers e não davam oportunidade para os grupos da cidade se apresentarem, uma vez que privilegiavam artistas e grupos da cidade de São Paulo. Reclamavam também, como jovem e ávida audiência de shows de rap, 
dos frequentes cancelamentos de shows sem retorno do valor pago pelo ingresso. Sentiam-se, em suma, desrespeitados.

A partir daí, passaram a se reunir em algumas praças no centro da cidade, região para onde confluíam os ônibus que serviam aos bairros da periferia onde moravam, facilitando o acesso. Com isso, puderam se articular a outros rappers, como parte de uma estratégia, considerada por eles como "consequência natural" da situação que estavam enfrentando, para confrontar o que percebiam como "os poderes estabelecidos", ou seja, os empresários e produtores que dominavam a cena rap da cidade à época.

Eles se colocavam também em oposição à liderança exercida por um rapper um pouco mais velho do que eles que já estava numa posição mais estabelecida, tendo se tornado conhecido por organizar eventos de hip hop na cidade. Esse rapper, que chamamos aqui de Pablo, aparece em diversos momentos da história do grupo como alguém que tinha propostas opostas. A oposição vai se ampliando ao longo dos anos, especialmente a partir de 1997, quando o próprio grupo passou a ganhar espaço nesse meio. Nesse período, enquanto eles procuravam um espaço para tocar, esse rapper, sendo alguns anos mais velho que a maioria dos jovens desse grupo, já produzia eventos de hip hop, participava do grêmio da escola e do movimento estudantil secundarista da cidade, o que acabou aproximando-o dos partidos políticos. Ele filiou-se ao PCdoB (Partido Comunista do Brasil) por meio movimento estudantil em 1997 e já tinha experiência em organizar atividades e aglutinar jovens para desenvolver campeonatos, passeios e atividades culturais na escola.

Com relação ao hip hop, os jovens expressavam restrições em especial com relação à forma como ele organizava seus eventos, vista por eles como um desserviço ao movimento, já que esvaziava sua dimensão política em prol de encontros que serviam apenas para dançar. Foi em reação a isso que o grupo primeiro se articulou.

"O Pablo... a parada dele é... assim... alugava um salão, aluga um equipamento de som, cobra a entrada e ganhava uma grana. Ele não abria espaço para ninguém, não dialogava com o movimento, soltava um jornal em que só ele escrevia, o jornal inteiro (...) A gente pensou: 'Pô, vamos montar um negócio alternativo, mais social, que a gente possa militar e que a gente seja mais independente e não dependa do empresário para ser o produtor, a gente mesmo se produz'. Aí surgiu a idéia de se montar uma posse" (entrevista com Fabiano, Campinas, 2006).

"Tinha as panelinhas do grupo X, do grupo Y, tinha os baileiros, como em todo lugar. Só que... assim... isso, como em todo lugar, prejudica. E aqui em Campinas a gente quis fazer uma coisa que fosse diferente disso tudo. Então, o pessoal que estava excluído das panelinhas e dos eventos dos baileiros se organizou um dia e falou: 'Ah pô, vamos fazer um evento só nós'. Começou assim como uma brincadeira. 'Ah, não... para... não sei o quê, isso dá trabalho". "Ah, vamos fazer isso sim, vamos meter a cara'. 'Ah, vamos!' Aí eu lembro até hoje que isso foi dentro de um salão, estava rolando um rap, tal. A gente tudo curtindo, tomando cerveja. 'Pô, vamos fazer!', 'vamos'. E ali foi uma sementinha que plantou na cabeça de cada um. Depois a gente começou a se juntar, fazer reunião em praça... [em] bar... a gente se encontrava... e até, outras vezes, no salão" (entrevista com Ivo, Campinas, agosto de 2005).

O ano de 1996 parece ter sido particularmente intenso. O grupo de rappers havia se adensado e já se reunia regularmente. Grupos de dançarinos do break também haviam começado a se reunir no centro da cidade e, em função do som e das aglomerações que produziam com suas apresentações, haviam passado a ser percebidos como ameaça à ordem pública. Quando seus encontros passaram a ser coibidos e controlados pelas autoridades, iniciou-se um ciclo de 
${ }^{7}$ Isso se deu em grande parte como decorrência da proeminência alcançada por artistas como Mano Brown e Thaíde \& DJ Hum. Para exemplos do tratamento dado ao rap pela grande imprensa, ver Especial Hip Hop (1998). Sobre os primeiros trabalhos acadêmicos sobre o rap, ver Andrade (1999). enfrentamentos com a polícia que os tornou mais visíveis no espaço público, em decorrência da cobertura jornalística dada aos confrontos.

É importante notar que o rap e o movimento hip hop alcançavam nessa época uma significativa legitimidade no cenário nacional, percebido ora como manifestação artística, ora como manifestação política, ora como ambos. Os álbuns de alguns artistas haviam alcançado bastante sucesso de vendas. Eles eram seguidamente entrevistados pela TV e pela imprensa escrita, atraindo a atenção da crítica especializada e dos cientistas políticos mais midiáticos, que alimentavam a discussão sobre o mais novo "fenômeno" político/cultural do país ${ }^{7}$ Os "desafios" e "combates" promovidos pelos dançarinos do break também ocupavam as manchetes dos jornais da cidade, embora suas lideranças não fossem tão vocais quanto os rappers.

O efeito disso para o grupo de jovens que se organizava em Campinas foi forte e imediato. Ao mesmo tempo em que os levava a se perceber como parte de algo importante e mais amplo, contribuiu também para que pudessem ser percebidos por outros como algo de valor no espaço da política. Como consequência, os encontros no centro da cidade passaram a atrair a atenção de políticos profissionais. Entre eles, destacou-se um vereador que acabara de ser eleito.

\section{II.2. A aliança com a política profissional}

${ }^{8}$ É preciso lembrar que no fim dos anos de 1990 o movimento negro já estava consolidado no Brasil (Avritzer 2009) e estava em curso uma mudança na sua pauta de reivindicações. Como parte das lutas pela construção e aceitação da identidade negra entre a população e contra a discriminação racial, o movimento havia passado a participar mais ativamente da política eleitoral (Gohn 2011, p.243).
Esse vereador havia iniciado sua carreira política aos 22 anos no movimento sindical, tendo se aproximado da política partidária poucos anos depois. Progressivamente, ele se constituíra como um importante articulador de movimentos de moradores de certos bairros da periferia da cidade, contribuindo para levar adiante reivindicações por saneamento básico, escolas e transporte. No seio do Partido dos Trabalhadores (PT), ele desempenhara a função de secretário de formação política e dos movimentos sociais. Tinha 31 anos quando foi eleito pela primeira vez para a câmara de vereadores de Campinas, em 1996.

Mais ou menos por essa época, o vereador, instado pelo movimento negro local, adotou a questão racial como uma de suas plataformas, o que o estimulou a tentar estabelecer essa aliança com os jovens rappers ${ }^{8}$. Como já dispunha de uma rede de apoio nos mesmos bairros em que moravam os jovens rappers envolvidos no movimento do centro da cidade, não foi difícil estabelecer contato com eles. Quando os procurou, por intermédio de uma antiga aliada, ativista do movimento de moradores de bairro muito conhecida na região, sua proposta era efetivar uma aliança com o grupo com a finalidade de promover eventos de rap dirigidos aos jovens negros da cidade.

"Só que em [19]97 o Tiãozinho se elegeu vereador e ele era do sindicato dos eletricitários. Ele era eletricista, negro e tal. Quando ele se elegeu, ele recebia muita crítica, porque ele era do movimento social, sindical e de moradores lá do DIC. O movimento negro começou a bater muito nele: 'Pô, você é o único vereador negro e de esquerda, você tem que fazer alguma coisa'. Ele começou a ser cobrado pela própria necessidade dele se aproximar. Aí ele priorizou no mandato dele essas áreas, o movimento negro e o hip hop. (...) Ele sentiu que o hip hop tinha um discurso social e ele achou que dava para fazer um trabalho. (...) Ele tinha muita crítica ao movimento de juventude do PT, porque predominava o movimento estudantil que tinha uns vícios e tal, então ele tentou se aproximar mais da juventude do hip hop, que seria mais interessante. (...) [No começo] o Tiãozinho dava uma força para ele (refere-se aqui ao Joel, outro garoto do grupo), para manter os equipamentos, comprar coisas novas, dava uma ajuda financeira com o mandato e organizava movimentos na periferia" (entrevista com Fabiano, Campinas, novembro de 2006).

A identificação entre os jovens e o vereador foi imediata. 
"Vereador [em] que eu sempre votei desde que comecei a votar foi o Tiãozinho e sempre fiz campanha para ele. Senti muito orgulho de fazer campanha para ele. Porque tudo na minha vida foi sempre identificação. Eu conheci o Tiãozinho na época que eu estava conhecendo a questão de partido, estava começando a achar legal, e aí ia rolar a campanha dele. Na sequência, eu comecei a vir muito no gabinete dele. Eu achei assim: 'Eu preciso estar fazendo a campanha para esse cara, eu preciso eleger esse cara de novo. Eu senti essa vontade"' (entrevista com Ivo, Campinas, agosto de 2005).

Isso não pode ser tratado como algo autoexplicativo. Uma análise das informações biográficas disponíveis permite atribuir essa identificação à homologia entre suas posições sociais, no sentido proposto por Bourdieu (2000b). O vereador, assim como a maioria dos jovens que fazia parte do grupo que se mobilizava por uma inserção artística no rap da cidade, era negro e de origem social modesta. Havia apenas finalizado o Ensino Médio antes de começar a trabalhar como eletricista. Além disso, ocupava, no campo da política, uma posição homóloga à ocupada pelos jovens no campo artístico, já que seu partido encontrava-se na oposição tanto na política nacional, quanto estadual e municipal e, no interior do partido, ele participava de um grupo minoritário, pouco expressivo.

É importante ter em mente que, nesse período, tanto a "questão racial" (Guimarães 2003), quanto os "problemas da juventude" (Novaes \& Alvim 2014) já haviam entrado na agenda de governos e organizações não governamentais nacionais e transnacionais. Nesse quadro, a visibilidade e a legitimidade obtidas pelo hip hop, percebidas como manifestações "autênticas" da juventude pobre moradora da periferia das grandes cidades tornaram esse tipo de aliança bastante comum. Ela aconteceu em diferentes cidades onde o hip hop alcançou um certo grau de legitimidade e visibilidade. Mesmo em Campinas, essa não foi a única aliança entre rappers e vereadores. Aquele rapper rival há pouco mencionado não tardaria a desenvolver uma aliança com outro partido, $\mathrm{o}$ PDT, que seguiu caminhos muito próximos ao que estamos relatando aqui, ainda que num momento posterior.

O primeiro efeito concreto da aliança entre os jovens rappers e o vereador foi a promoção de uma série de eventos de rap em espaços cedidos por associações de bairros, sindicatos e ONGs com as quais esse último tinha contato. Articulou-se, a partir daí, uma relação de interdependência entre eles.

Ao mesmo tempo, a aproximação com o vereador transformou o modo de atuação do grupo. Isso se deveu principalmente ao efeito socializador do contato com a política profissional (Bargel 2009). Distinguindo-se dos produtores de eventos que estavam estabelecidos no campo de divulgação do rap, os jovens passaram a dar um "objetivo social" às atividades que desenvolviam nesses primeiros meses. Nessa fase, isso significava fundamentalmente usar as apresentações de rap para levantar recursos para causas diversas. A apresentação artística era voluntária, a aparelhagem de som e luz era alugada com recursos fornecidos pelo vereador ou era tomada como empréstimo de sindicatos e associações diversas. Nesse período, a atuação dos jovens era definida por um discurso político que conceituava esse trabalho como "apoio aos excluídos".

"É... a gente aborda vários temas relacionados [com a] autovalorização do negro e do pobre e da mulher na sociedade. A gente fala um pouco também de consciência... assim... consciência política... consciência a respeito das drogas também. Porque na periferia... assim... as drogas são apresentadas para os meninos como uma coisa boa" (entrevista com Francisco, agosto de 2005).

Ao longo desse primeiro ano, jovens rappers e vereador engajaram-se também na produção de um festival de rap, denominado Rap em Trânsito. 
Organizado como um grande evento, reunindo importantes artistas do rap nacional, o festival passou a acontecer anualmente e com regularidade até 2004 (na última edição sob o nome de HIP HOP EM TRÂNSITO). Essa iniciativa trouxe vários ganhos para o grupo de jovens. Além de garantir a eles um espaço de bastante visibilidade para a divulgação do seu trabalho, foi instrumental para estabelecer sua reputação como grupo confiável, portador de um discurso autêntico, etc.

"E era muito louco, o público ia atrás e aí a gente começou a querer aprender um pouco mais, se formar politicamente. E foi daí que a gente deu um grande salto, assim, na minha opinião. Porque a gente passou de um evento, de um movimento de denúncia, para um movimento que além de denunciar vai pra ação, mostra um caminho, mostra de verdade a saída" (entrevista com Ivo, Campinas, agosto de 2005).

“A questão do hip hop não é só dançar, cantar, tem a questão social, a questão de passar conhecimento, discutir, de passar a questão da verdade. Quem somos nós, de onde viemos, o que somos, a questão de tudo ... discutir um pouco de tudo" (entrevista com Joãozinho, Campinas, dezembro de 2006).

Graças ao auxílio aportado pelo vereador, o festival contava com a participação de personalidades já firmadas do movimento hip hop campineiro e paulista, permitindo que os jovens entrassem em contato com empresários e artistas que ocupavam as posições mais proeminentes no universo do hip hop da época. Além disso, a concepção do festival como um evento ao mesmo tempo artístico e político contribuiu para fazer avançar a sua formação política. Os shows eram intercalados por debates que tratavam tanto do universo do rap e do hip hop, quanto de questões sociais importantes para eles como o problema racial, a violência urbana e a construção de movimentos sociais, por exemplo. Com o passar dos anos, o evento tornou-se cada vez mais estruturado e os organizadores chegavam a produzir e distribuir textos sobre as questões em debate, organizando oficinas de formação durante o mesmo, direcionadas à numerosa plateia.

Ainda que os interesses do vereador e dos jovens rappers fossem distintos, a aliança favorecia a ambos. De um lado, os jovens conseguiram, com o suporte material do vereador, divulgar suas canções, organizar seus eventos de rap, aglutinar mais jovens em torno do seu movimento. Por outro lado, o vereador conseguiu aproximar-se dos jovens e ampliar sua base eleitoral, enquanto executava um trabalho político de formação do grupo, direcionado para a formação de quadros para o partido.

O vereador foi responsável também por aproximar esses jovens de militantes de outras organizações, como aqueles que atuavam no seu próprio partido e no sindicato de que havia sido presidente. Em sua fase inicial, essas relações foram vividas pelos jovens como uma ampliação dos canais de suporte, já que por meio desses contatos o grupo obtinha apoio material significativo para, por exemplo, imprimir materiais de divulgação, tomar emprestado aparelhos de som necessários para os shows, etc. Com o passar do tempo, no entanto, os jovens passaram a ser convidados para tocar em eventos do sindicato, e mesmo a participar dos debates que ali tinham lugar.

“"Vai ter uma assembleia, vai ter uma paralisação não sei onde, vai ter tal coisa do sindicato. Vocês querem colar?' 'Quero sim'. 'Vocês podem ir lá para tocar'. Em vários eventos a gente ia para tocar” (entrevista com Ivo, Campinas, agosto de 2005).

Em 1998, os jovens foram instruídos pelo vereador a estruturar juridicamente o grupo. Um advogado foi indicado para auxiliá-los nisso e, como resultado, surgiu a associação. 
"O pessoal que já teve um contato [com o vereador] foi atrás e trouxe a assessoria dele para reunião e aí o pessoal do Tiãozinho começou a participar de fato, efetivo no [nome do grupo] também. Então era uma parceria muito forte que a gente fazia naquele começo, naquele tempo, e foi isso que ajudou" (entrevista com Ivo, Campinas, agosto de 2005).

A criação da associação pode ser vista como a concretização da transformação que aconteceu no próprio grupo de rappers. Se inicialmente o grupo encontrava-se nas ruas do centro da cidade, nessa segunda fase eles já utilizavam salas cedidas pelo sindicato para se encontrar. As conversas livres haviam sido substituídas por reuniões regidas por regras estabilizadas em estatutos, à imagem dos procedimentos que viram estruturar as reuniões do sindicato: pauta pré-definida, registro em ata, organização das intervenções, normas para o encaminhamento das decisões geradas nas reuniões, entre outros.

"Aí o Tiãozinho apresentou a gente nos sindicatos dos eletricitários, dos metalúrgicos. (....) A gente conheceu o Durval dos metalúrgicos, conhecemos o dos eletricitários (...) E aí a gente começou a se reunir nos sindicatos" (entrevista com Fabiano, Campinas, Campinas, novembro de 2006).

"Para mim foi um super aprendizado porque foi a partir daí que eu fui ter conhecimento dessas coisas de discriminação, racismo, o que estava por trás, como proceder, essa questão jurídica de como proceder. Criar uma organização, criar projeto de hip hop para apresentar aqui e ali, como chegar até a universidade. Foi a partir dali que a gente amadureceu, foi a partir do mandato propriamente do PT que a gente conseguiu criar o [nome do grupo], organizar os rappers e todas as coisas... foi através do mandato (...) do Tião que acabou dando um suporte para gente mesmo. Não vou dizer propriamente financeiro, mas o apoio, o suporte, apresentar para pessoas. Aí a gente acabou vinculando a questão da juventude, que é um espaço que se discute no PT, a gente vinculou o hip hop. Então ia ter alguma coisa da juventude em âmbito estadual ou nacional, alguém do hip hop que faz essa discussão também já ia como representante da juventude e do hip hop de Campinas para ter direito de voz, voto e espaço e mostrarem que o hip hop é um grupo organizado que também discute, que também tem um conhecimento, que sabe das necessidades do povo, quais as reais necessidades... muitos passam na própria pele. Então, para a gente foi um ganho" (entrevista com Joãozinho, Campinas, dezembro de 2006).

"A gente começou a desenvolver uma dinâmica de movimento social mesmo, marxista. Então as reuniões tinham inscrição para falar. Lógico que a gente não era tão burocrático que nem às vezes o movimento é, então não ficava marcando o tempo, não tinha aquela questão de ordem, questão de encaminhamento, isso não tinha. As reuniões eram em círculo, todo mundo falava, tinha votação se não tivesse acordo" (entrevista com Fabiano, Campinas, novembro de 2006).

Com isso, a capacidade de organização e mobilização do grupo aumentou de modo significativo, acompanhando também o desenvolvimento de um sem número de habilidades individuais específicas não totalmente ou diretamente relacionadas com as habilidades artísticas. A própria tarefa de organizar o evento Rap em Trânsito já exigia que aprendessem a produzir materiais escritos, como comunicados de imprensa e projetos para angariar recursos e patrocínio, que soubessem falar em público, principalmente para grandes públicos, que se engajassem no trabalho de aglutinar sua jovem audiência, o que fizeram por meio da produção e distribuição de panfletos e da mobilização de seus contatos, entre outros.

Ao longo do tempo, aqueles que se destacavam em termos da capacidade para a ação política - expressada no empenho na organização das atividades, na capacidade de se comunicar com a audiência ou, também muito importante, de escrever adequadamente - foram progressivamente sendo percebidos como lideranças do movimento, ao mesmo tempo em que também aprendiam a pensar nesses termos sobre si próprios. A percepção sobre o seu próprio valor havia 
também se transformado, como demonstra o fato de que muitos dos que ocupavam posições mais proeminentes na associação se submeteram aos exames de admissão a prestigiosas universidades, culminando na admissão de vários, principalmente em cursos de Ciências Sociais e Pedagogia na Unicamp ou na PUC-Campinas.

Também nesse período e por estímulo do vereador, a Associação passou a desenvolver esforços para se articular de forma mais sistemática aos outros segmentos do hip hop. A primeira providência foi destinar um espaço durante o evento Rap em Trânsito para os dançarinos de break e grafiteiros, o que aconteceu já em 1998.

Em cerca de três anos, os jovens da Associação conseguiram mobilizar cerca de 200 rappers para participar regularmente das atividades desenvolvidas por eles, além de vários grafiteiros e dançarinos do break. Além disso, estabeleceram contatos significativos com proeminentes praticantes do hip hop para além do município e passaram a dispor de uma infraestrutura que, embora limitada, era suficiente para realizarem suas reuniões. A associação passou, assim, a ser vista tanto pela imprensa, quanto pelos próprios artistas e pelos políticos profissionais, como porta-voz do "movimento hip hop" na cidade e, por extensão, como porta-voz da "juventude negra" e da "juventude da periferia" da cidade.

Nesse sentido, o conjunto de saberes adquiridos na prática, ao longo da atuação nos espaços abertos pelo vereador no universo da militância partidária e sindical, assim como os contatos que estabeleceram com outros rappers da cidade pode ser compreendido como um verdadeiro capital ativista, conforme proposto por Poupeau e Matonti (2004) para nomear as várias competências e habilidades que, úteis para a prática política, fazem crescer o valor dos ativistas que as possuem. Assim, se é verdade que todo esse processo não abriu muitas portas no mercado do rap para os jovens artistas, é inegável que acabou lhes valendo uma posição importante nas campanhas eleitorais municipais que aconteceram em 2000, nas quais se engajaram em apoio àquele vereador, nesse momento candidato à reeleição.

Já bastante imersos no espaço da política profissional, a participação nas eleições parecia algo natural, como relembraram depois. Exibiam nessa época um conhecimento já suficientemente preciso sobre o funcionamento da política partidária que lhes permitia perceber com bastante clareza sua importância na estratégia política do vereador e de seu partido. Por isso, ao se engajar na campanha, apresentaram uma pauta de reivindicações que deveria ser assumida pelos candidatos em troca do apoio explícito nas eleições. $\mathrm{O}$ acordo foi selado.

\footnotetext{
"Na época, o Toninho [candidato a prefeito] estava para ser eleito, então a gente apresentou o projeto para ele tal. Aí ele falou assim "Em cima disso aí vamos criar algumas políticas para o hip hop, se for eleito vocês têm um espaço garantido no governo". (...) E [foi] o Tiãozinho que mediou, porque o Tiãozinho era um dos braços direito do Toninho" (entrevista com Túlio, dezembro de 2006).
}

Essas reivindicações, tornadas públicas em manifesto de apoio à candidatura assinado por cada um deles e distribuído à população nas ruas e durante os eventos de que participavam, incluíam as seguintes demandas: (1) recursos para garantir a continuidade do Seminário Rap em Trânsito; (2) acesso a espaços públicos para realização de seus shows; (3) criação de espaços culturais na periferia da cidade; (4) a abertura de escolas públicas nos finais de semana para lazer e esporte; (5) desenvolvimento de projetos da prefeitura em parceria com o movimento hip hop, incluindo a realização de shows de rap, oficinas de break e grafite, palestras e debates; (6) luta contra discriminação racial, principalmente por meio da coibição da violência policial; e por fim, mas não menos 
importante, (7) a criação de uma Casa do Hip Hop, espaço a ser mantido pela prefeitura para a realização de várias atividades a serem desenvolvidas pelo movimento (reuniões, palestras, debates, oficinas etc.).

Desse conjunto, a criação da Casa do Hip Hop era considerada pelos jovens como um ponto particularmente importante. Esperavam que a casa contribuísse para estabilizar o grupo, dando a eles condições, inclusive financeiras, para se fortalecer como movimento. Inspiravam-se para isso no modelo da Casa do Hip Hop criada em Diadema, município da região metropolitana de São Paulo, por um prefeito do mesmo partido, cuja implementação implicara a criação de postos de trabalho remunerados pela prefeitura para seus administradores. Chamados de "coordenadores", esses haviam sido recrutados entre os ativistas do movimento hip hop.

O período das eleições foi vivido com muita intensidade.

"Eu deixei de comemorar o meu aniversário, que caiu no dia da eleição, para fazer boca de urna para ele e para o Toninho. Foi quando o Toninho ganhou a eleição aqui em Campinas. No dia da boca de urna do segundo turno era dia do meu aniversário. E o povo correndo atrás de mim. 'Cadê o cara? Cadê o cara?' E eu lá comemorando. Foi muito louco que eu ainda estava junto com o Fabiano, fazendo boca de urna junto, básico, os dois juntos. E aí eu falei: 'Pô hoje é meu aniversário e o presente que eu quero é que o Toninho ganhe essa eleição’. (...) Foi um puta lance assim, um momento inesquecível da minha vida" (entrevista com Ivo, Campinas, agosto de 2005).

Durante a eleição, os jovens estavam envolvidos em pelo menos dois embates. Um deles se dava entre os partidos que tradicionalmente se enfrentavam nas disputas eleitorais da cidade. O outro, vivenciado mais de perto pelos jovens rappers, consistia na luta em que engajaram pela mobilização da juventude da periferia. Nisso foram diretamente desafiados pelo grupo formado pelo rapper rival que apoiava candidatos do PDT, transformando a rivalidade que se iniciara no hip hop em rivalidade de campanha.

Como resultado, uma forte polarização entre os dois grupos marcou todo o período e foi como uma vitória pessoal que os jovens rappers vivenciaram os resultados favoráveis das eleições municipais. O vereador que apoiaram foi eleito com o maior número de votos entre os candidatos, o que garantiu a ele o posto de presidente da câmara municipal, e o candidato a prefeito do seu partido também foi eleito com folgada maioria.

\section{II.3. Vitória eleitoral e ativismo partidário}

A partir daí, iniciou-se uma série de negociações entre a associação e a nova administração municipal, que culminou com a inclusão do hip hop nas ações a serem desenvolvidas como parte da nova política cultural definida para o município. No entanto, mesmo em se tratando de promessa de campanha, isso não se fez sem lutas. Segundo depoimento de um alto dirigente do partido, membros importantes do diretório nacional defendiam que os prefeitos eleitos investissem prioritariamente no acesso da população menos privilegiada a expressões culturais mais legítimas, por meio do apoio a orquestras, grupos de dança clássica e contemporânea e museus, por exemplo. Vários deles eram contrários a investir no hip hop.

Esse dirigente argumentou que a oposição no seio do próprio partido impediu que as reivindicações dos jovens pudessem ser atendidas de maneira direta ou imediata pelo prefeito, apesar do apoio dado pelo vereador às demandas dos jovens. A demanda de criação da Casa do Hip Hop foi a que mais sofreu com isso, já que o empreendimento exigia, para ser bem-sucedido, a 
${ }^{9}$ Examinar as transformações do movimento ao longo do tempo e os efeitos da relação com o partido político sobre elas não implica tomar os movimentos e o Estado como esferas estanques. Ao contrário, vê-se aqui exemplos de processos de definição mútua ou de "coconstituição", que permitem construir uma visão mais complexa tanto das práticas e dos significados atribuídos a essas práticas (Carlos 2015, p.47), como de suas implicações sobre os arranjos institucionais.

${ }^{10}$ Cf. Avritzer (2012, p.392)

sobre a intensificação das canalização de um volume não desprezível de recursos durante toda a duração do mandato.

A alternativa encontrada pelo prefeito e pelos que ocuparam sucessivamente o comando da área cultural da prefeitura foi instruir os jovens a atuarem como protagonistas na busca de apoio e recursos no interior da própria administração. Isso resultou em seu engajamento nas assembleias do Orçamento Participativo, metodologia para decisão do uso de recursos que o prefeito eleito acabara de implementar (Avritzer \& Pires 2005; Tatagiba 2002; 2004).

As idas e vindas, negociações, esperanças e decepções que cercaram esse período implicaram mudanças importantes na agenda dos jovens. O tempo que investiam anteriormente na organização de shows e eventos ou nas reuniões para discutir temáticas políticas próximas de sua experiência cotidiana, como violência urbana, discriminação racial, preconceito e desigualdade, passou progressivamente a ser usado em reuniões com autoridades e funcionários de governo e em preparação para participação nas assembleias do Orçamento Participativo.

Inicia-se, então, uma segunda mutação do movimento. Na primeira, eles haviam passado a acentuar a dimensão social de seu trabalho e institucionalizaram juridicamente o agrupamento. Agora são levados a investir ainda mais no desenvolvimento de habilidades que os permitissem exprimir suas reivindicações dentro de um formato pré-definido pelo governo municipal ${ }^{9}$. No processo, tornaram-se capazes de se dirigir de maneira apropriada a outros políticos profissionais e a administradores do governo, a burilar seus argumentos, a redigir projetos em formatos adequados às normas definidas pela prefeitura. Desenvolveram, além disso, uma capacidade retórica e um conhecimento político que lhes permitia mobilizar um número cada vez maior de jovens para a participação nas assembleias do Orçamento Participativo, e também dialogar com os demais grupos mobilizados ali presentes.

"Aí foi legal porque (...) a gente sentiu que tinha condições para sentar para conversar com alguém. Porque até então a gente não tinha possibilidade de diálogo e a possibilidade que a gente viu era dentro do Orçamento Participativo, do OP. Nós falamos: 'Pô, o Orçamento Participativo é para juntar o povão, ir lá e disputar projeto, então vamos levar a nossa Casa'. Que era a Casa do Hip Hop e aí gente escreveu projeto, fomos na raça, começamos a se organizar, fazer mais reuniões e tal, e foi disputa. A gente foi disputar o Orçamento Participativo'" (entrevista com Ivo, agosto de 2005).

Apesar de tudo, os jovens não lograram incluir a Casa do Hip Hop como item de orçamento da prefeitura em nenhuma das assembleias que aconteceram entre 2000 e 2001. Contribuiu para isso o fato de que, nesses dois primeiros anos de mandato, as assembleias eram regionais e não temáticas, o que mudou posteriormente. Assim, a cada reunião, questões relativas às políticas de saúde, educação, habitação, entre muitas outras, competiam por recursos com questões relativas à política cultural. A assimetria era sempre muito grande, embora o grupo contasse sempre com o apoio expressivo de um grande número de jovens artistas do hip hop, que, mobilizados por eles, compareciam em peso às assembleias. Não ajudara a causa o fato de que essa fase da administração fora marcada também por bastante instabilidade na área da política cultural. Em menos de dois anos de governo, o secretário municipal de cultura havia sido substituído três vezes.

Tudo isso mudou em 2002, quando a administração iniciou uma fase de maior estabilidade. A partir daí os jovens iniciaram uma interlocução que se mostrou bastante produtiva com o novo secretário ${ }^{10}$, Valter Pomar. Esse oficial de governo, importante quadro nacional do partido e ligado, no interior do 
relações entre movimentos sociais e sistema político, associada à implantação do Orçamento Participativo. partido, a um grupo de oposição ao do vereador, desempenhou um papel determinante na vinculação dos jovens à política partidária.

Nessa fase, a metade deles já se filiara ao partido, participando ativamente da rotina partidária. Já estavam, portanto, bastante familiarizados com as lutas internas, conheciam as diferentes correntes ou, como são conhecidas no jargão da política partidária brasileira, as diferentes "tendências" que protagonizam as disputas internas. Valter Pomar investiu particularmente em tornar mais institucionalizadas as relações da administração com os jovens representantes do movimento hip hop, até então muito ligados ao vereador.

Ele explica:

"[Era importante] institucionalizar a relação do movimento hip hop com o governo. Porque a relação do movimento hip hop com o governo até esse momento era feita através daquelas pessoas que tinham relação política com o movimento ou um deputado estadual, um vereador, ou lideranças do [partido], ou com quem estava no governo. Mas era uma relação entre militantes políticos, não era uma relação institucional entre governo e movimento hip hop" (entrevista de pesquisa, Campinas, março de 2006).

Prometendo definir recursos para a criação da Casa do Hip Hop, ele iniciou uma interlocução seletiva com os jovens, por exemplo, recebendo no gabinete apenas aqueles que haviam se filiado a algum partido.

“A única condição que eu coloquei para eles foi que o Conselho não deveria ser restrito aos petistas, ele deveria ser um Conselho Municipal do hip hop de Campinas, o que significava que eles deveriam se esforçar sinceramente para incorporar o pessoal do $\mathrm{PCdoB}$, por exemplo, ao processo. E isso acabou acontecendo, esse é um outro movimento que aconteceu no processo, primeiro foi o afastamento... vamos dizer assim, o distencionamento (sic) deles conosco e um certo desprendimento deles com relação ao mandato do Tiãozinho e o segundo foi que no $\mathrm{PCdoB}$ houve uma diferenciação entre o grupo ligado ao Pablo e os demais que eram militantes do PCdoB mesmo" (entrevista com Valter Pomar, Campinas, março de 2006).

"Os demais hip hoppers que estavam ligados a partido políticos participavam. Foi aí que a maioria ganhou no discurso no Orçamento Participativo. Breaks interessados em dinheiro ganhou, ia e participava da OP. Grafiteiros. As pessoas praticamente contribuíram e muito para [ganhar a] verba no OP, para essa verba do OP vir pro hip hop" (entrevista com Heitor, Campinas, outubro de 2005).

"Eu não tinha um bom relacionamento com o Valter Pomar, porque o Valter Pomar ele não queria discutir comigo, ele discutia com os filiados e não com os caras do hip hop" (entrevista com Túlio, Campinas, dezembro de 2006).

Isso provocou uma clara hierarquização no interior do grupo de rappers, reforçada pela progressiva centralização do planejamento e da implementação das ações políticas nas mãos dos poucos jovens que tinham acesso direto a membros do governo. Uma nítida divisão do trabalho se instaurou entre aqueles que tinham livre trânsito na prefeitura e aqueles que faziam o trabalho que eles denominavam "de rua", atuando em eventos, oficinas e iniciativas de mobilização dos jovens. Para além disso, todos se viam mais e mais envolvidos em atividades que, como nos contaram depois, denominavam na época como "burocráticas" - reuniões e preparação para as negociações, por exemplo - com as quais gastavam cada vez mais energia e mais tempo.

Procurando obter apoio para a obtenção de recursos para a Casa do Hip Hop, foram investidos esforços para que o próprio hip hop pudesse ser percebido pela população em geral como objeto interessante e legítimo da política cultural. Para o secretário, era necessário que o projeto de criação da Casa do Hip Hop deixasse de ser visto como "política de favorecimento a um grupo específico", isto é, podemos dizer, como retribuição aos ativistas. Para isso, deveria ser 
apresentado como demanda da "juventude negra e popular", no sentido mais genérico do termo.

Com esse objetivo, foi criado, então, um Conselho Municipal do Hip Hop, claramente instrumentalizado para a cooptação de eventuais opositores ao projeto da Casa. Entende-se assim porque o secretário fez questão de nele incorporar militantes de outros segmentos e de outros partidos também atuantes na cidade. A missão desse conselho seria, além de formular propostas de políticas direcionadas para a juventude negra e popular, gerir a Casa do Hip Hop quando essa fosse criada.

A incorporação dos militantes de outros partidos ao conselho foi muito mal recebida pelos jovens que estavam lutando pela concretização da Casa do Hip Hop, pois representava para elas um fortalecimento de antigos rivais, aqueles com os quais haviam disputado palmo a palmo a eleição para a prefeitura.

\begin{abstract}
“A própria Casa do Hip Hop de Campinas... o histórico dela é um histórico muito ligado à questão política também, porque existia um grupo de membros do movimento hip hop que eram ligados ao PT, o nosso que era ligado ao PCdoB, outros que eram apartidários, e outros só a questão cultural. Quando o PT ganhou as eleições no ano 2000, o Toninho virou prefeito. Esse setor do PT que era ligado ao hip hop e tinha ligação com o Prefeito e o partido do poder, conseguiu articular a Casa do Hip Hop. Então, foi na gestão do PT que ela surgiu, só que existiu nessa época também um tencionamento (sic) desse grupo político com outros grupos. Eles meio que acharam ... até por inexperiência, eles acharam que a Casa do Hip Hop era deles. (...) Então aconteceram guerras, eu nunca tinha visto isso antes, guerras políticas dentro do movimento hip hop, de grupos políticos se digladiando" (trecho extraído da entrevista com Pablo, Campinas, dezembro de 2006).
\end{abstract}

Isso deu origem à primeira onda de desengajamento que o grupo vivenciou.

\title{
II.4. O desengajamento
}

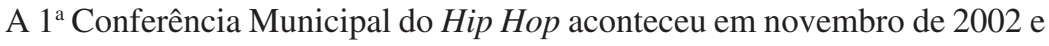
marcou o primeiro rompimento no interior do grupo de jovens rappers que havia permanecido na liderança do movimento. Foram excluídos, tanto da organização da conferência, quanto da participação substantiva nela, aqueles jovens que não haviam se filiado ao partido do prefeito. Segundo eles, foram excluídos também aqueles que eram filiados ao partido mas que atuavam no subgrupo do vereador. Ao mesmo tempo, foram incluídos membros do grupo com o qual haviam rivalizado há muito tempo.

"A coisa foi ficando meio desgastada, algumas pessoas foram entrando em conflito internamente. (...) Por causa de incompatibilidade de ideais. Quando a gente ganhou a prefeitura aqui de Campinas, de 2000 para 2001, algumas pessoas foram para o governo, algumas pessoas eram linha de frente do hip hop também eram ligados a alguns partidos de esquerda, mais PT e PCdoB. As que estavam no PT também tinham as questões das tendências, um era de uma tendência, outro era de outra, aí que a questão do rap começou a virar muito partidária, muito tendenciosa. A coisa começou meio que a se misturar. (...) muitos grupos que estavam chegando viram a guerra pela metade e acabou se tornando meio que pessoal para muitos" (entrevista com Joãozinho, Campinas, dezembro de 2006)

O custo foi alto. Os jovens deixados de lado viveram a exclusão com grande ressentimento, manifestando publicamente durante a Conferência seu incômodo com o que viam como "interferência" do secretário de cultura no movimento. Ao final, produziram um manifesto explicando seu rompimento com a associação. Como nos explicaram depois durante as entrevistas, afastaram-se e recusaram-se a aceitar as condições do secretário porque queriam manter-se fieis a suas posições políticas. 
“As pessoas começaram a se identificar com várias forças políticas do PT e o negócio foi pulverizando. Eu tive umas divergências com o Tiãozinho, tive umas críticas ao mandato dele e aí eu acabei me afastando e teve mais gente que se afastou pelos mesmos motivos que eu" (entrevista com Fabiano, Campinas, novembro de 2006).

No entanto, esse rompimento, ao que parece, não estava ao alcance de todos. Como foi possível averiguar por meio de um recenseamento que fizemos, apenas os jovens que não dependiam dos políticos profissionais e que dispunham de condições objetivas para garantir sua sobrevivência fora do circuito de trocas impulsionado por eles romperam de fato com o grupo. Uma das jovens, por exemplo, havia se tornado professora em escola municipal, outra havia sido admitida, por concurso, num cargo de assessoria na câmara dos vereadores, outro dispunha de um diploma de curso profissionalizante que lhe permitia ganhar razoavelmente a vida como trabalhador autônomo na área de manutenção de computadores. E assim por diante.

Os que permaneceram eram, sem exceção, ainda muito dependentes daquilo que denominamos aqui de retribuições militantes. Essa noção, proposta por Gaxie (1977; 2005), permite compreender a disposição ao ativismo como resultado pelo menos parcial da participação em sistemas de gratificações implementado pelas organizações, partidárias e outras, que dependem do ativismo de seus membros para sobreviver. Vistas por esse ângulo, as retribuições podem ser materiais, como por exemplo a oferta de postos de trabalho e cargos que permitem aos ativistas viver por e do ativismo, ou podem ser simbólicas, como o sentimento de pertencimento a um grupo ou a honra social associada à ocupação de um determinado posto hierárquico. Note-se, como propõe Fillieule (2009), que as retribuições oferecidas pela organização podem ter um caráter menos utilitarista, como é o caso daquelas que estão vinculadas, por exemplo, ao processo de socialização militante e que se manifestam como oportunidades para a aquisição de habilidades importantes para o ativismo, como a competência técnica num determinado assunto ou problema social ou mesmo uma capacidade de "resistência". Um dos paradoxos inerentes aos sistemas de retribuições, no entanto, consiste no fato de que, ao mesmo tempo em que essas podem criar sentimentos de pertencimento ao grupo, podem também ser objeto de disputas, desacordos e ressentimentos no interior desse.

Para o caso analisado aqui, percebe-se que as retribuições militantes desempenharam um papel importante para garantir a continuidade do engajamento de alguns jovens. Um deles, por exemplo, havia sido aprovado em concurso público e havia se tornado funcionário da prefeitura num cargo administrativo subalterno, no qual desenvolvia atividades de rotina. A participação no movimento hip hop levou à sua transferência para a secretaria de cultura, onde passou a ocupar um cargo cujo salário era melhor e onde exercia tarefas de direção e controle. Outro assumiu, logo após as eleições, um cargo de assessor também na secretaria de cultura. Havia ainda vários que sobreviviam da remuneração recebida em troca da realização de oficinas de rap, break e grafite em escolas e outras agências públicas por onde circulavam jovens dos grupos trabalhadores. Para eles, era uma nova perspectiva profissional que se abria. Naquela época, o hip hop passara a ser visto pelos formuladores de políticas públicas como um importante recurso para mediar a comunicação com os "jovens da periferia". As oficinas desenvolvidas nas escolas e, por exemplo, em abrigos para jovens infratores da lei, serviam para encaminhar discussões sobre drogas, doenças sexualmente transmissíveis, HIV etc. Hoje essas intervenções são parte da rotina da política social. A atividade profissionalizou-se, passou a ser denominada "educação social" e o acesso a ela é controlado, pelo menos em parte, por concursos públicos. Na época, no entanto, os jovens prestadores do serviço eram chamados de "oficineiros do hip hop" e recebiam uma remuneração 
modesta, mas regular, considerada por eles como interessante porque acreditavam estar rompendo com a história familiar de trabalhos manuais sem se render aos trabalhos que percebiam como pouco interessantes. Percebiam, assim, essa nova atividade como mais livre da "exploração" e das "hierarquias", embora seu acesso a elas fosse necessariamente mediado por políticos profissionais.

"Minha irmã... apesar de trabalhar... ter a vidinha dela, ter o carrinho do ano que ela conseguiu comprar. Meu irmão tem o trabalho dele, é casado tal. Mas, assim, a qualidade de vida que eu tenho é muito melhor. Apesar de ficar quatro meses desempregado, eu sou uma pessoa sem crise (...) Eu faço tudo o que eu gosto, eu vivo do que eu gosto. Isso é importante, hoje eu estou aqui dando aula de break, amanhã eu posso estar dando aula de grafite. Eu faço o que eu gosto, eu ando do jeito que eu quero. Olha, eu estou trabalhando, eu estou barbudo, cabelo sem cortar e não vou cortar mesmo até dezembro, entendeu. Ninguém fala nada. Agora é chato você entrar numa empresa e 'por que você está com essa barba?', 'por que você está de bermuda, porque você está de tênis?', isso aí que é a coisa chata. Então eu sou feliz assim. Então, [é] a qualidade de vida que eu tenho" (entrevista com Heitor, novembro de 2006).

Essas retribuições materiais e simbólicas que o partido passou a oferecer a vários indivíduos assegurou a continuidade do próprio grupo que, nesse período, já não existia fora das malhas partidárias ou de governo, não desenvolvendo qualquer atividade artística ou política independente da prefeitura.

Isso contribuiu para que o grupo restante se fechasse cada vez mais. A burocratização não abria espaço para entrada de novos militantes, e a restrição da oferta de recompensas materiais e simbólicas contribuiu para aguçar os conflitos entre os próprios membros, que passaram então a disputar os recursos em questão.

"Mas aí a coisa foi tomando outro rumo, as pessoas pensando em cargo, tem a ver com as oficinas, ganhar aquele dinheirinho que a prefeitura dava, então acabou dispersando um pouco" (entrevista com Vânia, Campinas, agosto de 2005).

"Teve gente que prestou concurso público e passou. Começou a fazer militância e tal. Quando o Toninho ganhou... o Toninho do PT ganhou, as pessoas apoiaram o mandato dele. Fizeram campanha política, show em palanques tal. Quando ele ganhou, o Toninho deu cargo para muita gente. Uns foram para a cultura, esse que prestou concurso público tinha passado, tinha subido de cargo, sabe, [refere-se ao Fabiano que, ao passar no concurso, obteve um cargo de confiança na Secretaria de Cultura], aqueles cargos de agente comissionado, funcionário comissionado, ele vai para um setor. Foi para [trabalhar como] agente cultural e as pessoas começaram a militar com o hip hop e essas pessoas elas começaram, são muito inteligentes, começaram a ler muito, Marx, tudo sobre Filosofia, começaram a entender mais [sobre] política. Era a saída dos guetos para um outro mundo, o mundo da inteligência. Eu não acho eles ruins, nunca achei. Achei eles inteligentes até por demais, muito inteligentes. Então... eles saíram dos guetos e evoluíram intelectualmente e aprenderam a lidar com a política e ver como são as coisas, como se faz política, como se faz movimento, como se organiza. Mas isso aí, nessa época, a [nome do grupo] já estava quebrada, já estava tudo deturpado. Foi onde o PT ganha [e] dá cargo para muita gente. Deu por obrigação porque eles ajudaram, era uma aliança política. Muita gente se filiou ao partido, vivia no diretório. Outros ganharam cargos no movimento negro campineiro" (entrevista com Heitor, Campinas, outubro de 2006)

Apesar de tudo, a criação do Conselho Municipal do Hip Hop em 2004 foi um marco importante na institucionalização do movimento. Tanto o Conselho quanto a Casa do Hip Hop criada posteriormente eram geridos por um pequeno número de jovens que lograram ser eleitos para os cargos disponíveis. Eram 21 conselheiros, distribuídos entre rappers, breakers e grafiteiros, mais sete suplentes. Coube ao secretário de cultura indicar, entre eles, aqueles que assumiriam os postos remunerados de coordenadores da Casa do Hip Hop, ficando encarregados de administrá-la. O sistema de retribuição militante continuou a 
prevalecer, agora associado ao projeto de cooptação em andamento. Assim, foram indicados os dois rappers que já ocupavam cargos comissionados na prefeitura, uma grafiteira e um dançarino de break.

A maneira como foi conduzida a indicação dos coordenadores da Casa do Hip Hop por parte do Secretário da Cultura deixa claro o interesse político que a administração municipal tinha tanto em relação ao hip hop, quanto em relação aos jovens ativistas. O secretário conta:

\begin{abstract}
A gente contratou como assessores da secretaria algumas lideranças do movimento. (...) Essas pessoas que foram contratadas, elas coordenavam a Casa. Esse é um aspecto importante. (...) Nós queríamos uma relação institucionalizada. Ou seja, a Casa é um espaço público, portanto gerido pelo poder público através de agentes municipais. Agora, a programação da Casa e o que seria feito lá dentro ia ser decidido pelo Conselho Municipal do Hip Hop" (...)
\end{abstract}

\{Quem indicou esses nomes para vocês?\}

Ninguém. Foi escolha nossa por razões técnicas e políticas. Quando você conhecer os três você vai entender no ato. O [nome do rapper] já estava contratado, mas os outros três que a gente foi contratando ao longo do processo... Você vai entender" (entrevista de pesquisa, Campinas, março de 2006).

De fato, os jovens escolhidos destacavam-se bastante dos outros. Eles eram muito engajados politicamente e apresentavam muito bem seus argumentos em defesa do partido e da maneira como a administração da casa foi encaminhada. Poderiam ser considerados, de fato, como ativistas do partido.

Essa fase, no entanto, correspondeu apenas ao curto período que restava para o final do mandato. Como o partido perdeu as eleições seguintes e o prefeito foi substituído, os jovens também foram substituídos na coordenação da casa por membros do conselho mais próximos do partido vitorioso. Assim, tendo se afastado do mercado artístico do hip hop, no qual não haviam nem mesmo conseguido entrar, e sem financiamento governamental, o grupo se extinguiu.

Em termos individuais, vários entre os membros do movimento que trabalharam nas oficinas apoiadas pela prefeitura reconverteram essa experiência em atividade profissional, passando a vender seu trabalho para órgãos públicos, ONGs e outras organizações dispostas a financiar projetos educativos e sociais. Duas das garotas finalizaram seus cursos superiores e chegaram a obter um título de mestrado. Alguns poucos permaneceram nos cargos de assessoria a políticos do partido. Um deles iniciou mais recentemente uma carreira na política profissional. Foi candidato a vereador nas eleições de 2012, não tendo sido eleito. Os outros voltaram às atividades profissionais que desenvolviam anteriormente, desligadas do universo artístico e ativista.

Para além disso, a própria transição para a vida adulta desses jovens que iniciaram o ativismo no hip hop entre 12 e 16 anos de idade contribuiu para que a dedicação à militância se tornasse menos intensa ou até mesmo deixasse de existir. No período em que o partido perdeu as eleições municipais, vários deles estavam se casando e alguns já estavam tendo seus primeiros filhos. Estavam, assim, sendo levados a arcar com responsabilidades maiores, o que exigia um maior investimento no trabalho estável remunerado.

Quando o novo partido eleito assumiu o governo da cidade em 2005, não havia mais mobilizações coletivas em torno do hip hop. No entanto, a Casa do Hip Hop de Campinas funciona até hoje. Suas atividades estão centradas em oficinas de iniciação ao rap, ao break e ao grafite, num formato bastante escolar. 


\section{Conclusões: $o$ ativismo fora das organizações políticas é possível?}

O surgimento dos primeiros artistas e grupos de hip hop no Brasil acompanhou de perto, pelo menos em termos cronológicos, a recriação da política partidária no país, no ambiente hiper-politizado dos primeiros anos de retorno à democracia. A intensidade com que o movimento hip hop arregimentou e mobilizou jovens pobres das periferias das grandes cidades industriais brasileiras contribuiu para adensar, de maneira um tanto inesperada, o debate político dos anos 1990, abrindo caminho para que essa população pudesse de fato ser considerada, em termos substantivos, como parte dele.

Ao acompanhar as experiências vivenciadas por um grupo de jovens negros, moradores da periferia de uma grande cidade, no seu envolvimento com hip hop e, a partir daí, com a política profissional, o artigo identifica as mudanças profundas provocadas pela experiência sobre a visão que os jovens tinham de si mesmos e sobre a maneira como conceituavam o próprio movimento que haviam contribuído para criar.

A análise dessas mudanças revela os efeitos ambíguos desse processo. Embora, por um lado, a aproximação com o hip hop tenha dado condições para que esses jovens pudessem construir uma visão de futuro que rompia com sua história social familiar, por outro lado, a posição econômica e social por eles ocupada não lhes permitiu ir muito além disso, o que é bastante compreensível numa sociedade em que a distribuição das oportunidades era e continua a ser muito desigual. A aproximação com a política profissional tornou-se, em consequência, uma saída possível já que encontraram ali apoio concreto para desenvolver e ampliar sua ação propriamente política.

Essa aproximação, no entanto, teve seus custos. A relação entre os jovens do hip hop e os políticos profissionais exigiu um alto investimento em tempo e energia dos primeiros na aquisição de habilidades e competências fundamentais para atuarem no espaço do ativismo partidário. Isso foi feito às expensas do projeto pessoal que acalentavam, no qual a carreira artística ocupava uma posição central, colocando-os numa situação de dependência com relação ao sistema de retribuições alimentado pelo partido com recursos da prefeitura. Essas retribuições, embora garantissem sua sobrevivência e o afastamento das posições de trabalho precárias, não era suficiente permitir a continuidade do investimento no próprio hip hop.

Um dos interesses do estudo aqui apresentado reside na possibilidade que ele abre para se estudar o tipo particular de relação que se desenvolveu entre os jovens e o partido político e, posteriormente, quando esse último ganha as eleições municipais, entre os jovens e o governo municipal. Observa-se, em primeiro lugar, que o esquema clássico de conceituação de um movimento social como "desafiadores" da política institucional (Tilly 1988), já que sua própria constituição como movimento dependeu da ação de políticos profissionais. Ao mesmo tempo, embora uma leitura apressada possa levar a concluir que o movimento só existiu por causa da intervenção dos políticos profissionais, é preciso lembrar que os políticos profissionais se interessaram pelo movimento apenas quando este já estava em plena luta por seus interesses, ocupando espaços públicos e enfrentando a polícia para garantir a realização de seus shows. Em segundo lugar, é útil lembrar que, embora não tenha sido objeto do estudo examinar os efeitos das relações com o movimento sobre os políticos profissionais, sobre o partido político e sobre as políticas públicas que esse priorizou quando assumiu o poder, a discussão apresentada aqui indica a produtividade de se formular essa relação como algo mais fluido e mutuamente influenciável do que tem sido admitido pelas visões que atribuem posições mais estanques às duas esferas ${ }^{11}$.

${ }^{11}$ Conferir em Alonso (2009), 
Carlos (2015) e Goldstone (2003) recenseamentos finos desse debate, assim como discussões dos limites associados a cada posição e propostas analíticas com o objetivo de superá-los.
A dissolução do grupo associada à derrota do partido nas eleições e à entrada de um novo prefeito indica a fragilidade da posição em que acabaram situados. Nesse sentido, esse caso permite indagar sobre o lugar dos movimentos sociais no modelo de democracia em vigor no Brasil e em outras sociedades. Mais precisamente, a análise indica as dificuldades de se manter o ativismo político sem a estabilização oferecida pelas organizações, sejam elas partidárias ou sindicais, ao mesmo tempo em que revela os limites desse arranjo.

Rosangela Carrilo Moreno (rocarrilo@gmail.com) é Doutora em Educação pela Universidade Estadual de Campinas (Unicamp) e Pesquisadora Associada do Focus (Unicamp). Vínculo Institucional: Grupo de Pesquisas em Educação, Instituição e Desigualdades, Faculdade de Educação, UNICAMP, Campinas, SP, Brasil.

Ana Maria Fonseca de Almeida (aalmeida@unicamp.br) é Pós-Doutora pela École des Hautes Etudes en Sciences Sociales (França), Professora Associada (Livre-Docente) da Faculdade de Educação da Universidade Estadual de Campinas (Unicamp) e Coordenadora do Focus (Grupo de Pesquisa sobre Educação, Instituições, Desigualdades, Unicamp). Vínculo Institucional: Departamento de Educação, Conhecimento, Linguagem e Arte (DELART - Faculdade de Educação), UNICAMP, Campinas, SP, Brasil.

\section{Referências}

Alonso, A., 2009. As teorias dos movimentos sociais: um balanço do debate. Lua Nova, 76, pp.49-86. DOI: 10.1590/s0102-64452009000100003

Alves, L.; Batista, A.A.G.; Ribeiro, V.M. \& Ernica, M., 2015. Seleção velada em escolas públicas: práticas, processos e princípios geradores. Educação e Pesquisa, 41, pp.137-152. DOI: 10.1590/s1517-97022015011488

Andrade, E.N., ed., 1999. Rap e educação, rap é educação. São Paulo: Selo Negro.

Avritzer, L., 2009. Participatory Institutions in Democratic Brazil. Baltimore: Johns Hopkins University Press. 2012. Sociedade Civil e Estado no Brasil: da autonomia à interdependência política. Opinião Pública, 18(2), pp.383-398. DOI: 10.1590/s0104-62762012000200006

Avritzer, L. \& Pires, R.A.A., 2005. Orçamento participativo, efeitos distributivos e combate à pobreza. Teoria \& Sociedade, número especial, pp.68-89.

Bargel, L., 2009. Socialisation politique. In O. Fillieule; L. Mathieu \& C. Péchu, eds. Dictionnaire des mouvements sociaux. Paris: Presses de Sciences Po.

Becker, H., 1963. Outsiders. Studies in the Sociology of Deviance. New York: The Free Press.

Becker, H. \& Strauss, A.L., 1956. Careers, Personality, and Adult Socialization. American Journal of Sociology, 42, pp.253-263. DOI: $10.1086 / 222002$

Bourdieu, P., 2000. Espaço social e gênese das classes. In ___ O poder simbólico. $3^{\mathrm{a}}$ ed. Rio de Janeiro: Bertrand Brasil.

Carlos, E., 2012. Movimentos sociais e instituições participativas: efeitos organizacionais, relacionais e discursivos. Tese de Doutorado. São Paulo: Universidade de São Paulo.

Contamin, J.-G., 2007. Genre et modes d'entrée dans l'action collective. L'exemple du mouvement pétitionnaire contre le projet de loi Debré. Politix, 78, pp.13-37. DOI: 10.3917/pox.078.0013.

Costa, M. \& Koslinski, M.C., 2012. Escolha, estratégia e competição por escolas públicas. Pró-Posições, 23(2), pp.195-213. DOI: 10.1590/s0103-73072012000200013

Dowbor, M., 2012. A arte da institucionalização: estratégias de mobilização dos sanitaristas (1974-2006). Tese de Doutorado. São Paulo: Universidade de São Paulo.

Ernica, M., 2013. Desigualdades educacionais no espaço urbano: o caso de Teresina. Revista Brasileira de Educação, 18(54), pp.523-788. DOI: 10.1590/s1413-24782013000300002

Fillieule, O., 2001. Proposition pour une analyse processuelle de l'engagement individuel. Revue Française de Science Politique, 51(1-2), pp.199-217. DOI: 10.3406/rfsp.2001.403613

,2009. De l'objet de la définition à la définition de l'objet. De quoi traite finalement la sociologie des mouvements sociaux? Politique et Sociétés, 28(1), pp.15-36. DOI: 10.7202/001723ar

Fillieule, O. et al., 2007. Introduction: Militantisme et hiérarchies de genre. Politix, 78, pp.7-12. DOI : 10.3917/pox.078.0003

Gaxie, D., 1977. Économie des partis et rétributions du militantisme. Revue Française de Science Politique, 27, pp.123-154. DOI: $10.3406 /$ rfsp.1977.393715

2005. Rétribution du militantisme et paradoxes de l'action collective. Revue Suisse de Science Politique, 11, pp.157-188. DOI: 10.1002/j.1662-6370.2005.tb00051.x

Gohn, M.G., 2011. Movimentos Sociais na Contemporaneidade. Revista Brasileira de Educação, 16(47), pp.333- 361. DOI: $10.1590 / \mathrm{s} 1413-24782011000200005$

Goldstone, J.A., 2003. Introduction. Bridging Institucionalized and Noninstitucionalized Politics. In J. Goldstone, ed. States, Parties, and Social Movements. Cambridge, UK: Cambridge University Press.

Guimarães, A.S.A., 2003. Acesso de negros às universidades públicas. Cadernos de Pesquisa, 118, pp.247-268. DOI: $10.1590 / \mathrm{s} 0100-15742003000100010$ 
Hughes, E., 1958. Men and Their Work. Glencoe: The Free Press.

Koslinski, M.C. \& Carvalho, J.T., 2015. Escolha, seleção e segregação nas escolas municipais do Rio de Janeiro. Cadernos de Pesquisa, 45, pp.916-942. DOI: 10.1590/198053143352

Lahire, B., 2004. Sucesso escolar nos meios populares: as razões do improvável. São Paulo: Ática.

Matoni, F. \& Poupeau, F., 2004. Le capital militant: essai de définition. Actes de la Recherche em Sciences Sociales, 155, pp.5-11. DOI: 10.3917/arss.155.0004

Novaes, R. \& Alvim, R., 2014. Movimentos, redes e novos coletivos juvenis. Um estudo sobre pertencimentos, demandas e políticas públicas de juventude. In J.S. Leite Lopes \& B. Heredia, eds. Movimentos Sociais e Esfera Pública. O mundo da participação: burocracias, confrontos e aprendizados inesperados. Rio de Janeiro: CBAE.

Saint Martin, M., 1993. L'espace de la noblesse. Paris: Métaillé.

Sawicki, F., 2003. Les temps de l'engagement: À propos de l'institutionnalisation d'une association de défense de l'environnement". In L. Jacques, ed. La politisation. Paris: Belin.

Tatagiba, L., 2002. Os Conselhos Gestores e a democratização das políticas públicas no Brasil. In E. Dagnino, ed. Sociedade civil e espaços públicos no Brasil. São Paulo: Paz e Terra.

2004. A institucionalização da participação: os conselhos municipais de políticas públicas na cidade de São Paulo. In L. Avritzer, ed. A participação em São Paulo. São Paulo: Editora UNESP.

Tilly, C., 1988. From Mobilization to Revolution. New York: Random House.

\section{Outras fontes}

Especial Hip Hop, 1998. Caros Amigos, 3, número especial. 


\section{When Young Hip Hop Activists Meet Party Politics}

\section{Abstract}

The degree in which social movements can thrive in alliance with political parties is a relevant question for participatory democracy. This article discusses the ambiguous effects of the alliance established between a group of young hip-hop artists and politicians in a Brazilian big city located in the state of Sao Paulo in the 2000's. It explores an interactionist perspective of activism, conceptualizing it as a dynamic social activity and stressing its temporal dimension. Based on in-depth interviews with members of the hip-hop group and party leaders, the study shows how the relationship established between them allowed the youth to actively contribute to the development of the city's hip hop movement and to be recognized as it's spokespeople. Over time, though, their increasing dependence from the party hindered their artistic production, and gave room for internal competition, leading to the group dissolution. By showing how these relations developed, the study reveals the possibilities and limits of social movements dependence from political parties, especially when the later win executive positions in government.

KEYWORDS: Activism; Social Movements; Hip-Hop; Party Politics; Brazil.

This is an Open Access article distributed under the terms of the Creative Commons Attribution Non-Commercial License which permits unrestricted non-commercial use, distribution, and reproduction in any medium provided the original work is properly cited. 


\section{Apêndice 1}

Quadro 1A - Jovens do Movimento Hip hop de Campinas - características selecionadas*

\begin{tabular}{|c|c|c|c|c|c|}
\hline Nome (fictício) & $\begin{array}{l}\text { Idade no momento } \\
\text { de aproximação } \\
\text { com o Hip hop }\end{array}$ & $\begin{array}{l}\text { Escolarização em } \\
2006\end{array}$ & $\begin{array}{l}\text { Idade do } \\
\text { primeiro } \\
\text { trabalho }\end{array}$ & $\begin{array}{l}\text { Primeira } \\
\text { experiência de } \\
\text { trabalho }\end{array}$ & $\begin{array}{l}\text { Trabalho em } \\
2006\end{array}$ \\
\hline Antônio & Sem dados & $\begin{array}{l}\text { Ensino Médio Técnico } \\
\text { Designer }\end{array}$ & Sem dados & Sem informação & $\begin{array}{l}\text { Free-lancer como } \\
\text { designer e artista } \\
\text { do grafite }\end{array}$ \\
\hline Cinthia & 16 anos & Sem dados & 14 anos & $\begin{array}{l}\text { Restaurante e bar } \\
\text { de um tio. }\end{array}$ & $\begin{array}{l}\text { Oficinista de hip } \\
\text { hop }\end{array}$ \\
\hline Fábia & 14 anos & Sem dados & Sem dados & $\begin{array}{l}\text { Babá (sem carteira } \\
\text { de trabalho) }\end{array}$ & Sem trabalho \\
\hline Fabiano & 14 anos & $\begin{array}{l}\text { Economia } \\
\text { (PUC-Campinas), } \\
\text { Filosofia (Unicamp). } \\
\text { Abandonou ambos }\end{array}$ & 16 anos & $\begin{array}{l}\text { Ajudante geral em } \\
\text { escola de tênis }\end{array}$ & $\begin{array}{l}\text { Funcionário da } \\
\text { prefeitura munici- } \\
\text { pal (atendente em } \\
\text { biblioteca munici- } \\
\text { pal) }\end{array}$ \\
\hline Francisco & 16 anos & $\begin{array}{l}\text { Ensino Médio; } \\
\text { Formação marcenaria }\end{array}$ & 16 anos & $\begin{array}{l}\text { Auxiliar de } \\
\text { escritório }\end{array}$ & $\begin{array}{l}\text { Oficinista de hip } \\
\text { hop }\end{array}$ \\
\hline Geraldo & 12 anos & $\begin{array}{l}\text { Ensino Supe- } \\
\text { rior, Publicidade } \\
\text { (PUC-Campinas) }\end{array}$ & 16 & Sem informação & Grafite \\
\hline Heitor & 13 anos & $\begin{array}{l}\text { Ensino Médio } \\
\text { (supletivo) }\end{array}$ & 18 anos & $\begin{array}{l}\text { Vendedor em loja } \\
\text { de calçado }\end{array}$ & $\begin{array}{l}\text { Oficinista de hip } \\
\text { hop }\end{array}$ \\
\hline Ivo & 14 anos & $\begin{array}{l}\text { Ensino } \\
\text { Médio, Técnico } \\
\text { Processamento de } \\
\text { Dados }\end{array}$ & 18 anos & Sem informação & Motoboy \\
\hline Joãozinho & 16 anos & $\begin{array}{l}\text { Ensino Médio } \\
\text { (incompleto) }\end{array}$ & 9 anos & Empacotador & $\begin{array}{l}\text { Oficinista de hip } \\
\text { hop }\end{array}$ \\
\hline Maiara & 15 anos & $\begin{array}{l}\text { Superior } \\
\text { Completo, Ciências } \\
\text { Sociais } \\
\text { (PUC-Campinas) - } \\
\text { iniciando mestrado }\end{array}$ & 18 anos & $\begin{array}{l}\text { Secretária em } \\
\text { cursinho popular }\end{array}$ & $\begin{array}{l}\text { Assessora de } \\
\text { vereador }\end{array}$ \\
\hline Márcio & 17 anos & $\begin{array}{l}8^{\mathrm{a}} \text { ano do Ensino Fun- } \\
\text { damental }\end{array}$ & 14 anos & $\begin{array}{l}\text { Vendedor de } \\
\text { doces e salgados }\end{array}$ & $\begin{array}{l}\text { Empresa de } \\
\text { eventos e } \\
\text { produção }\end{array}$ \\
\hline Pablo* & 15 anos & $\begin{array}{l}\text { Filosofia (Unesp). } \\
\text { Jornalismo (PUC- } \\
\text { Campinas). } \\
\text { Abandonou ambos }\end{array}$ & Sem dados & $\begin{array}{l}\text { DJ e produtor de } \\
\text { shows }\end{array}$ & $\begin{array}{l}\text { Secretaria da } \\
\text { Cultura }\end{array}$ \\
\hline Túlio & & Ensino Médio & Sem dados & Sem dados & $\begin{array}{l}\text { Manutenção na } \\
\text { área de } \\
\text { informática } \\
\text { (autônomo) }\end{array}$ \\
\hline Vânia & 15 anos & $\begin{array}{l}\text { Pedagogia } \\
\text { (PUC-Campinas), } \\
\text { Mestrado (Unicamp) }\end{array}$ & Sem dados & Sem dados & $\begin{array}{l}\text { Professora na rede } \\
\text { municipal de } \\
\text { Campinas }\end{array}$ \\
\hline
\end{tabular}

* Rapper rival

Fonte: As autoras, a partir de entrevistas de pesquisa. 
Quadro 2A - Formação escolar e profissão de pais e avós dos jovens

\begin{tabular}{|c|c|c|c|c|}
\hline Nome & Avós maternos & Avós paternos & Mãe & Pai \\
\hline Antônio & Não sabe & Não sabe & $\begin{array}{l}\text { Ensino superior } \\
\text { Educação Física } \\
\text { incompleto Do lar }\end{array}$ & $\begin{array}{l}\text { Ensino superior } \\
\text { Administração e } \\
\text { Teologia Autônomo }\end{array}$ \\
\hline Cinthia & Não sabe & Não sabe & Não informou & Não informou \\
\hline Fábia & Não sabe & Não sabe & $\begin{array}{l}\text { 3o. ano do ensino fun- } \\
\text { damental Cozinheira }\end{array}$ & $\begin{array}{l}5^{\circ} . \text { ano do ensino fun- } \\
\text { damental Pedreiro }\end{array}$ \\
\hline Fabiana & Não sabe & Não sabe & Não informou & Não informou \\
\hline Fabiano & Garimpeiro Doméstica & Caseiro Doméstica & $\begin{array}{l}4^{\circ} . \text { ano ensino funda- } \\
\text { mental Auxiliar de } \\
\text { transporte escolar }\end{array}$ & $\begin{array}{l}\text { Ensino técnico - } \\
\text { eletrônica Encarregado } \\
\text { de hidráulica }\end{array}$ \\
\hline Francisco & Agricultura & Não sabe & Doméstica & $\begin{array}{l}\text { Falecido - acidente de } \\
\text { trabalho }\end{array}$ \\
\hline Geraldo & $\begin{array}{l}\text { Tesoureiro (sem } \\
\text { certeza) Do lar }\end{array}$ & $\begin{array}{l}\text { Sabe apenas que avô } \\
\text { veio de família de } \\
\text { fazendeiros }\end{array}$ & $\begin{array}{l}\text { Superior completo } \\
\text { Psicologia }\end{array}$ & $\begin{array}{l}\text { Professor de Medicina } \\
\text { na PUC Campinas }\end{array}$ \\
\hline Heitor & $\begin{array}{l}\text { Trabalhador manual - } \\
\text { encostado pelo INPS - } \\
\text { Do lar }\end{array}$ & & $\begin{array}{l}\text { 5o. ano do ensino fun- } \\
\text { damental. Foi trabalhar } \\
\text { como vendedora } \\
\text { quando marido faleceu }\end{array}$ & Falecido Bancário \\
\hline Ivo & Montador em fábrica & Não sabe & $\begin{array}{l}\text { Ensino Médio } \\
\text { Funcionária pública }\end{array}$ & $\begin{array}{l}\text { Sem informação } \\
\text { (conheceu o pai aos } 12 \\
\text { anos) }\end{array}$ \\
\hline Joãozinho & Não sabe & Não sabe & $\begin{array}{l}\text { Doméstica } \\
\text { Semi-analfabeta }\end{array}$ & Pedreiro Alfabetizado \\
\hline Maiara & Não informou & Não informou & Não informou & Não informou \\
\hline Márcio & Sem informação & Pedreiro Cozinheira & Cozinheira Sem estudo & $\begin{array}{l}\text { Falecido Dinamitador } \\
3^{a} \text { série }\end{array}$ \\
\hline Pablo & Não sabe & Não sabe & $\begin{array}{l}\text { Empresa de outdoor } \\
\text { vendedora Fez ensino } \\
\text { supletivo e ensino su- } \\
\text { perior (Publicidade) }\end{array}$ & Vendedor ambulante \\
\hline Túlio & Agricultura & Agricultura & $\begin{array}{l}3^{\circ} \text { ano do ensino funda- } \\
\text { mental Doméstica }\end{array}$ & $\begin{array}{l}5^{\circ} \text { ano do ensino funda- } \\
\text { mental Comerciante }\end{array}$ \\
\hline Vânia & Não sabe & Não sabe & Não sabe & Não sabe \\
\hline
\end{tabular}

Fonte: As autoras, a partir de entrevistas de pesquisa. 